\title{
ヒンダードアミン・塩素化ポリエチレン有機ハイブリッドの 熱処理過程における動的粘弾性の変化
}

\author{
飛澤 泰樹*1 - 尅 馳飛 ${ }^{* 1, \dagger} \cdot$ 秋山 三郎*1
}

（受付 2002 年 3 月 1 日・審査終了 2002 年 4 月 12 日）

\begin{abstract}
要 旨 塩素化ポリエチレン（CPE）とヒンダードアミン系低分子化合物（LA-57）からなる有機ハイ ブリッドについて, 熱処理過程における相分離, 低分子の結晶化などの構造形成およびそれによる動的粘

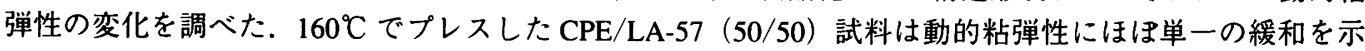
すため, 相溶系である。この試料を $100^{\circ} \mathrm{C}$ で熱処理すると，まず二つの緩和が現れ，その後高温側の緩和 が次第に小さくなり，最後に消失する。これは，熱処理過程での相分離およびLA-57の結晶化によるも のである. また，熱処理の後期過程で見られた $E^{\prime}$ の大幅な増大は，CPEのセグメントを取り込んでいる LA-57の結晶がフィラーとしてだけでなく，架橋点としても働いたためであると考えられる.
\end{abstract}

\section{1 序言}

塩素化ポリエチレン（CPE）のような極性ポリマーに 多官能性のヒンダードフェノール系低分子化合物を分散 した有機ハイブリッド系では，マトリックスポリマーの ガラス転移点より高い温度で新たな緩和を呈する1).21. この新しい緩和現象は低分子リッチドメイン内の異分子

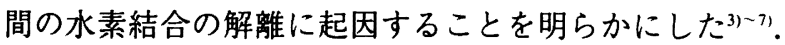
相図をもつポリマーブレンドでは，同一組成のブレンド が温度によって相溶したり，相分離したりすることがよ く知られている。しかし，これまでの研究は相分離過程 での構造形成機構について精力的に行われてきたが，構 造と物性に着目した研究はあまり見当たらない ${ }^{8)}$. 本研 究では,ヒンダードフェノール系低分子化合物に比べて, CPE との親和性が高いヒンダードアミン系低分子化合 物を用い, 熱処理過程における相分離と結晶化による構 造形成と動的粘弾性変化を調べ，それらの関連性につい て考察した。

\section{2 実験}

\section{1 試料の作製}

マトリックスポリマーとして塩素化ポリエチレン (CPE，昭和電工(株)，エラスレン $401 \mathrm{~A}$ ，塩素含有量 40

*1 東京農工大学工学部有機材料化学科 (384-8588 小金井市 中町 2-24-16)

†現所属機関・所在地：華東理工大学材料科学与工程学院 (雪) 200237 上海市梅隴路 130 号)

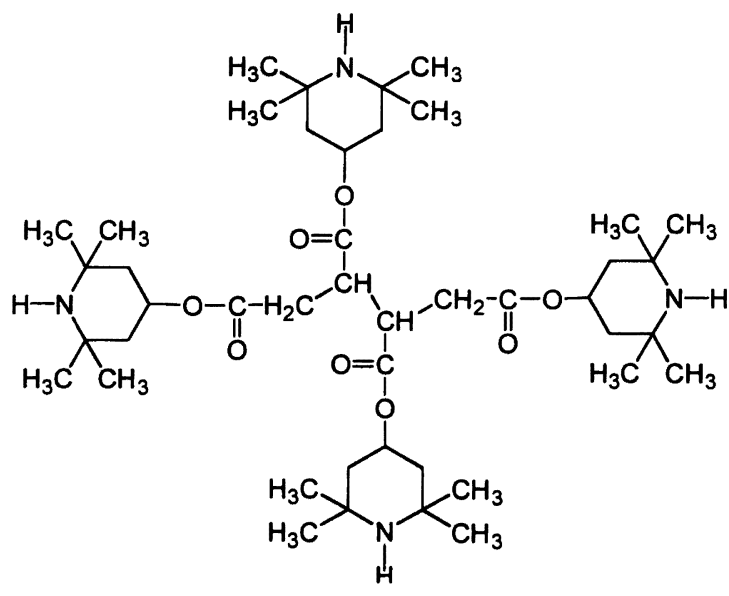

Fig. 1. Chemical structure of tetrakis(2,2,6,6-tetramethyl-4piperidyl)-1,2,3,4-butane tetracarboxylate (LA-57).

wt％)，添加剤として Fig. 1 に示すテトラキス $(2,2,6,6-$ テトラメチル-4-ピペリジル)-1, 2, 3,4-ブタンテトラカ ルボキシレート（旭電化工業(株), ADKSTAB LA-57) を用いたＬA-57 の性状として，分子量は791であり， DSC によるガラス転移温度と融点はそれぞれ $39,132^{\circ} \mathrm{C}$ である。

混練は(株)井元製作所製のミニロールを用いて約 $50^{\circ} \mathrm{C}$ で行った。 まず, CPEのみを約 5 分間混練し, 続 けて LA-57を入れて約 10 分間混練して十分に分散させ た.その際, CPE とLA-57の重量比を 1：1に統一した。 得られた混練試料をホットプレスで $160^{\circ} \mathrm{C}, 20 \mathrm{MPa}$ の 圧力下で 30 分間保持した後, 液体窒素中で急冷して厚 
さ的 $0.1 \mathrm{~mm}$ と $1.0 \mathrm{~mm}$ のシートを作製した。熱処理試 料は上記のシートを所定の温度 $\left(40,100^{\circ} \mathrm{C}\right)$ に保たれ た恒温槽中に所定の時間置いた後, 形成された構造をそ のまま保持するため, 液体窒素中で急冷することにより 作製した。

\section{2 動的粘弾性測定（DMA）}

得られたシートから $30 \times 7 \mathrm{~mm}^{2}$ の試料片を切り出し, セイコー電子工業(株) 製の DMS 200 を用いてその試料 の動的粘弾性を測定した。測定条件として，昇温速度は $3^{\circ} \mathrm{C} / \mathrm{min}$, 周波数は $1 \mathrm{~Hz}$, 振幅は $5 \mu \mathrm{m}$, 測定モードは 引張りである.

\section{3 示差走査型熱量測定（DSC）}

CPE マトリックスに分散しているLA-57 分子の結晶 化を確認するために，(株)リガク製 DSC 8230 を用いて 示差走査型熱量測定を行った. 約 $10 \mathrm{mg}$ の試料をアル ミニウム製の試料パンに封入して, $30^{\circ} \mathrm{C}$ から $-60^{\circ} \mathrm{C} ま$ で冷却してから昇温速度 $10^{\circ} \mathrm{C} / \mathrm{min}$ で $160^{\circ} \mathrm{C}$ まで昇温 し, 熱処理過程で形成されたLA-57 結晶の融解特性を 測定した。

\section{4 フーリエ変換赤外分光法（FT-IR）}

FT-IR 測定は日本電子(株) 製 JIR-WINSPEC 50 フーリ 工変換赤外分光光度計を用いて分解能 $2 \mathrm{~cm}^{-1}$, 積算回 数 100, 透過法で行った。純 LA-57 の試料は, その粉末 を $\mathrm{KBr}$ とまぜて，ガラス状の LA-57 と熱処理試料は， 厚み $0.1 \mathrm{~mm}$ のフイルムにしてから測定した.

\section{3 結果と考察}

Fig. 2 に $160^{\circ} \mathrm{C}$ で溶融プレスしたCPE/LA-57 のブレ ンド試料 (未処理試料) の貯蔵弾性率 $E^{\prime}$, 損失弾性率 $E$ ”および損失正接 $\tan \delta$ の温度依存性を示す。この試 料はほほ単一の緩和を示すため, LA-57 は, 二つの緩和 を示したヒンダードフェノールの系と違って CPE と相

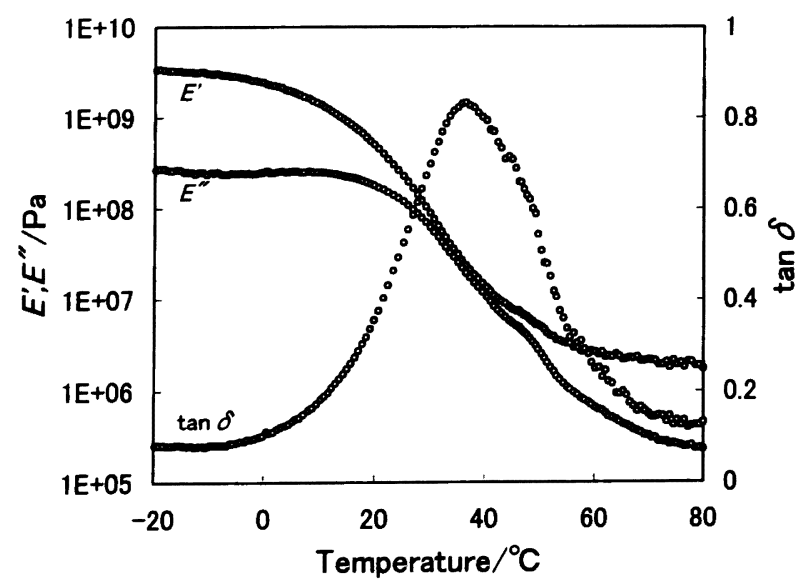

Fig. 2. Temperature dependence of $E^{\prime}, E^{\prime \prime}$ and $\tan \delta$ at 1 $\mathrm{Hz}$ for CPE/LA-57 (50/50) blend pressed at $160^{\circ} \mathrm{C}$.
溶であることがわかった。また，各種組成の CPE/LA-57 の相溶性を調べた結果, CPE/LA-57は上限臨界共溶温 度（UCST）型の相図を示すことを DMA 測定から確認 した。

この相溶状態にあるプレス試料を低温の 2 相領域に置 くと, 相分離が開始される. $100^{\circ} \mathrm{C} て ゙$ 所定の時間を経っ てから試料を急冷し，相分離状態を凍結させ，もう一度 低温から動的粘弾性を測定すると, Fig. $3(\tan \delta)$, Fig. $4\left(E^{\prime}\right)$ に示す結果が得られる. non-treatment は未処理 試料を表し, 数字は熱処理時間を表す (単位は分). Fig. 3 において, 未処理試料はほほ単一のピークを示し, そ の後熱処理することによってそのピークはまず低温側と 高温側の二つのピークに明確に分かれた。低温側のピー クは CPEマトリックスのガラス転移に起因し, 高温側

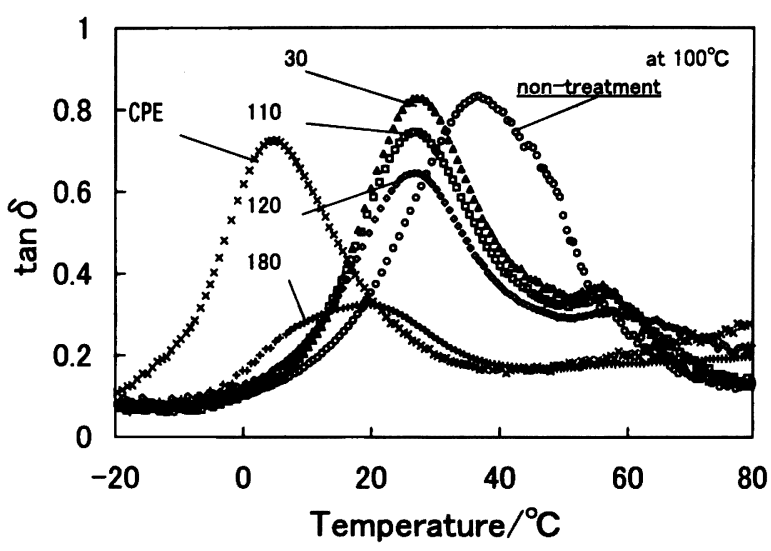

Fig. 3. Effects of heat treatment at $100^{\circ} \mathrm{C}$ on temperature dependence of $\tan \delta$ of CPE/LA-57 (50/50) blend pressed at $160^{\circ} \mathrm{C}$. The numbers shown in the figure are heat-treatment times (min).

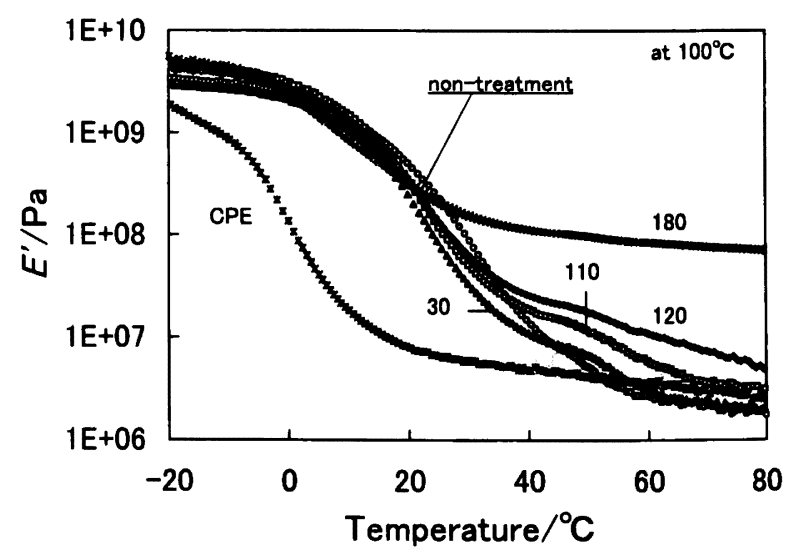

Fig. 4. Effects of heat treatment at $100^{\circ} \mathrm{C}$ on temperature dependence of $E^{\prime}$ of CPE/LA-57 (50/50) blend pressed at $160^{\circ} \mathrm{C}$. The numbers shown in the figure are heat-treatment times (min). 
のピークはLA-57アモルファスドメインのガラス転移 に起因すると考えられる．本来相分離のみなら，二つの $\tan \delta$ ピークはそのまま順次 CPEのガラス転移による $\tan \delta$ ピークと LA-57 のガラス転移による $\tan \delta$ ピーク に向かってシフトしていくと考えられる.しかし, 熱処 理時間の増大とともに, 高温側のピーク強度は次第に減 少し，熱処理時間が 180 分に達した段階でそのピークは 完全に消失した.この挙動は相分離だけでは説明できず, 熱処理の後期過程でLA-57の結晶化も起こっているこ とを示唆している.

Fig. 4 において, $50^{\circ} \mathrm{C}$ 付近の分散は熱処理の初期段階 でより顕著に現れたが，その後熱処理時間の増加ととも に小さくなり，180 分になったとき消失した。これは相 分離により形成されたLA-57 ドメインがガラス状態か ら結晶に変わったためである.

また, 110 分以上の熱処理による $E^{\prime}$ の大幅な增大は 注目すべきである，熱処理によりCPEマトリックス内 で形成された LA-57 の結晶が単なるフィラーとして働 くなら， $E^{\prime}$ の充てん効果は下記の Guth 式"を用いて見 積もることができる.

$$
E=E_{0}\left(1+2.5 V_{f}+14.1 V_{f}^{2}\right)
$$

ここで，E， $E_{0}$ は，それぞれフィラーが充てんされて いる系の $E^{\prime}$ ，フィラーが充てんされていない系の $E^{\prime}$ を表す. $V_{f}$ はフィラーの体積分率である.CPE/LA-57 (50/ 50）における LA-57 の体積分率は 54\% であり，Guth 式 を用いて計算した結果，単なるフィラー効果による $E^{\prime}$ の增加率 $\left(E / E_{0}\right)$ は 6.5 である. しかし, 180 分間熱処

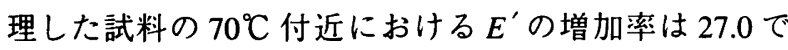
あった。これは，熱処理過程で形成された LA-57 結晶 が複雑な高次構造を有し，フィラーとしての役割以外に 架橋点としても働いたと考えられる。このことは，LA57 の結晶粒子を CPE に分散した試料 (Sample UC), 同 じ組成の熱処理 $\left(100^{\circ} \mathrm{C} / 180\right.$ 分) 試料 (Sample AC) の $E^{\prime}$ の比較からも確認できる. Fig. 5 から, 同一組成であ ってもその物性は LA-57 結晶の構造により大幅に変化 することがわかった．LA-57 の結晶粒子を CPE に分散 した試料の $70^{\circ} \mathrm{C}$ 付近での $E^{\prime}$ の増加率は 8.8 であり, Guth 式に基づいて計算した值（6.5）より若干大きい. これは, LA-57の体積分率が Guth 式の適用範囲 $\left(V_{f}<\right.$ 30\%）を超えたためである。一方，熱処理試料の $E^{\prime} の$ 增加率は 27.0 にも達し, およそ LA-57 の結晶粒子を CPE に分散した試料の 3 倍である. DSC 測定により両サン プルのLA-57の結晶の融解熱を調べた結果, 熱処理試 料の融解熱はわずか純 LA-57の3 分の 1 であった。こ れは, $100^{\circ} \mathrm{C} て ゙ 180$ 分間熱処理した試料において CPE マトリックスに分散している LA-57 分子の結晶化は部 分的に生ずることを意味している．LA-57 ガラスの $E^{\prime}$

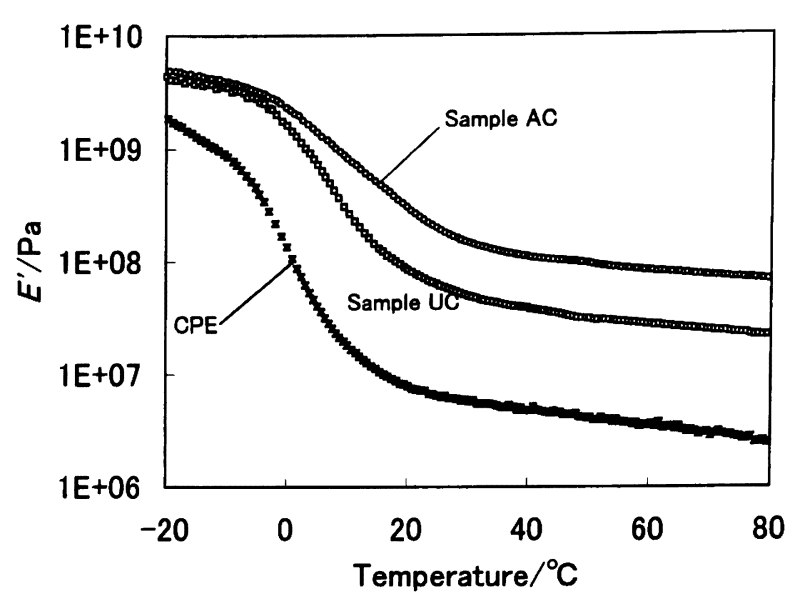

Fig. 5. Temperature dependence of $E^{\prime}$ at $1 \mathrm{~Hz}$ for CPE, Sample AC (the pressed CPE/LA-57 (50/50) blend heattreated at $100^{\circ} \mathrm{C}$ for $180 \mathrm{~min}$ ), and Sample UC (the unpressed CPE/LA-57 (50/50) blend).

がLA-57 結晶のそれより小さいため, フィラーとして の充てん効果は LA-57 の結晶粒子を CPE に分散した試 料よりもっと小さい. したがって, 熱処理試料において 架橋点としての効果をもっと大きく見積ることができ る.

熱処理により形成された LA-57 結晶の高次構造を明 らかにするためには, 速度論的な考察が必要となる，結 晶性/非晶性ポリマーのポリマーブレンドにおいて, 結 晶性ポリマーが結晶化する際に, 結晶ラメラ間の非晶部 に非晶性高分子が取り込まれるのかどうかは, 主に結晶 化速度と非晶性高分子の拡散速度との関係によって決ま るとされている(10,11)．LA-57 は低分子であるためその結 晶化速度が速いことに対し, CPE は高分子であるため その拡散速度は遅い．したがって，LA-57 が結晶化する 際にはCPE 鎖が取り込まれることも十分に考えられる。

熱処理による LA-57 の結晶化を確認するために, DSC 測定を行い,その結果をFig. 6 に示す。純 LA-57 は非 常に鋭い吸熱ピークを示し，規則正しい結晶を有する。 未処理試料の DSC 曲線には融解ピークが見られなかっ た. 熱処理時間が 30 分のとき, 非常に小さい吸熱ピー クが見られた。これは 30 分まで主に相分離が進行し, 結晶化があまり進んでいないことを意味している。熱処 理時間が 30 分を超えると, 吸熱ピークが段々大きくな っていくことが見られた．また，吸熱ピークの形状から 見ると, 熱処理試料の吸熱ピークは純 LA-57 の結晶の 融解によるピークに比べてかなりブロードであることが わかった。これは, 相分離により形成されたLA-57リ ッチドメインにおいてランダムにパッキングしたLA-57 分子をわずかに調整し，新たにできた不完全な微結晶の 融解によるものであると考えられる，その場合， CPE 


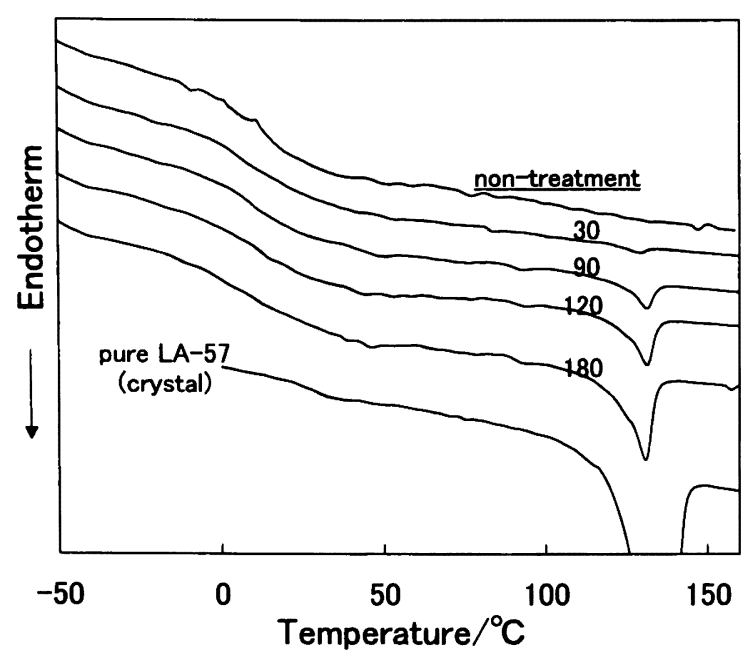

Fig. 6. DSC curves of pure LA- 57 and the heat-treated CPE/LA-57 (50/50) samples. Scan rate was $10^{\circ} \mathrm{C} / \mathrm{min}$. The numbers shown in the figure are heat-treatment times (min).

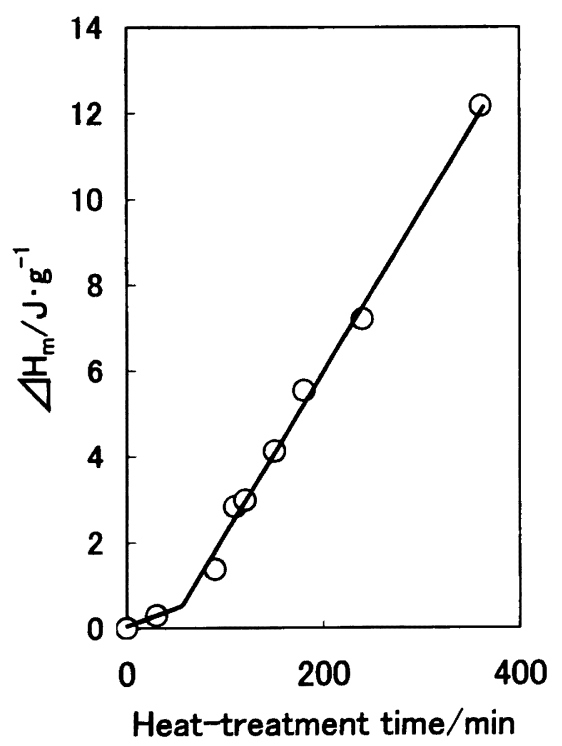

Fig. 7. $\Delta \mathrm{H}_{\mathrm{m}}$ as a function of heat-treatment time for CPE/ LA-57 (50/50) blend pressed at $160^{\circ} \mathrm{C}$.

の分子鎖がまだLA-57 の結晶に残されている.

各熱処理時間に対して融解熱をプロットした結果を Fig. 7 に示す.このグラフから熱処理時間が 30 分付近 まではほとんど結晶化が進行せず，それ以後急激に結晶 化が進行していることがわかった。このことから，30 分付近までは相分離が優先的に進行し，その後結晶化が 急速に進行するといえる.

Fig. 8 に結晶状態のLA-57 とガラス状態のLA-57の FT-IR のスペクトルを示す. 結晶状態の LA-57 には 3438 $\mathrm{cm}^{-1}$ にフリーの $\mathrm{NH}$ 基の伸縮振動に帰属するバンドと $3334 \mathrm{~cm}^{-1}$ に自己会合した $\mathrm{NH}$ 基の伸縮振動に帰属する

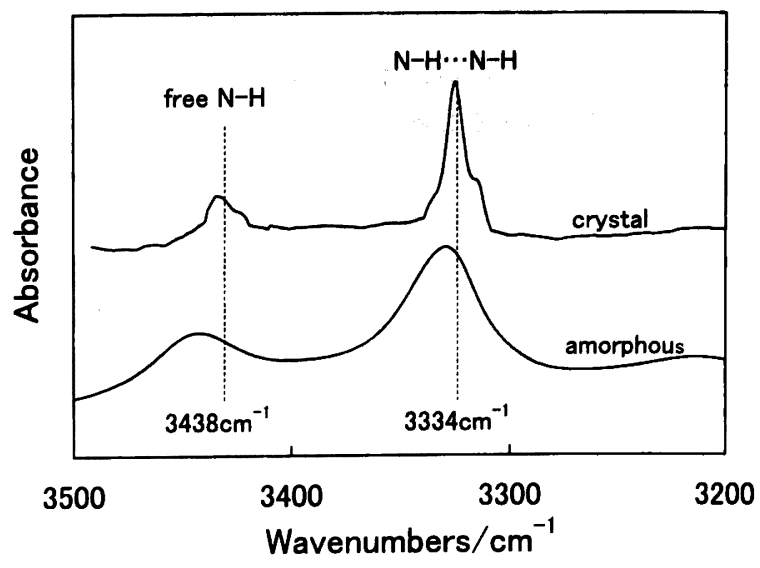

Fig. 8. Infrared spectra of initial LA-57 (crystal) and vitrified LA-57 (amorphous) in the amino-stretching region.

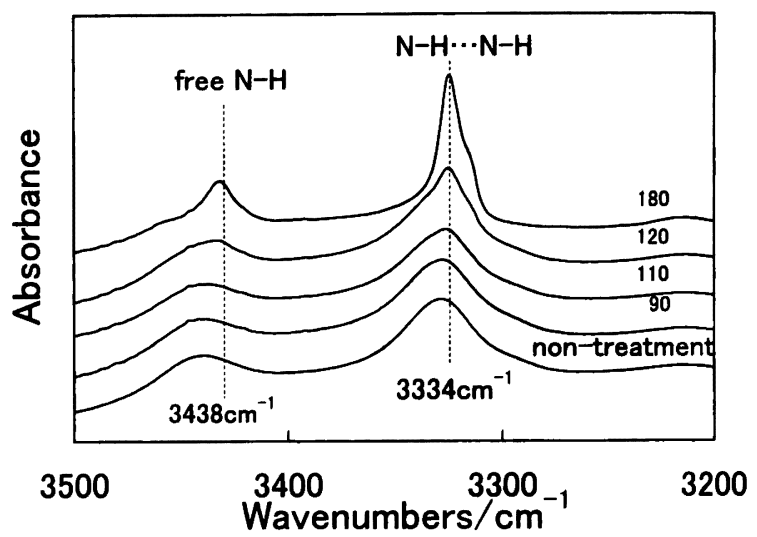

Fig. 9. Influence of the heat-treatment at $100^{\circ} \mathrm{C}$ on infrared spectrum of CPE/LA-57 blend pressed at $160^{\circ} \mathrm{C}$ in the amino-stretching region. The numbers shown in the figure are heat-treatment times $(\mathrm{min})$.

バンドが見られた，一方，ガラス状態のLA-57にも二 つのバンドが見られたが，その位置は結晶状態のものに 比べて高波数側にシフトし，それぞれ $3443 \mathrm{~cm}^{-1}$ と 3339 $\mathrm{cm}^{-1}$ であった。 また，その形状も結晶状態の LA-57 と は異なり, 比較的ブロードであった。これは, ガラス状 態では結晶状態と比べて $\mathrm{NH}$ 基間の距離が大きく，かつ 一定ではないためであると考えられる.

熱処理による分子間相互作用の変化を確認するため に, FT-IR 測定を行った。その結果を Fig. 9 に示す. 未 処理試料の場合, $3443 \mathrm{~cm}^{-1}$ と $3339 \mathrm{~cm}^{-1}$ に二つのバン ドが見られ，そのスペクトルの形状も比較的ブロードで あり, Fig. 8 に示した非晶性の LA-57 と相似している. これは, 未処理試料内で結合距離の異なる水素結合が種 種の形成されているが, CPE とLA-57 の分子間水素結 合があまりできていないことを示唆している。このこと は, LA-57の構造はヒンダードフェノールとは異なって 
窒素原子は直接六員環中にあり，隣接しているメチル基 による遮へい効果がもっと大きいためであると考えられ る. 熱処理時間が比較的に短いとき，スペクトルの形状 に大きな変化が見られなかった。しかし，熱処理時間が 110 分を超えると, スペクトルの形状は鋭くなり，その 強度も増大したが，異分子間の水素結合が観察されなか った．このことから，熱処理により現れた高温側の緩和 (Fig. 3) はLA-57 リッチドメインのガラス転移に起因 すると推定できる.もちろん，熱処理の進行につれて， 相分離によりできたLA-57ドメインがアモルファスか ら結晶と変わるため, アモルファス分が少なくなり，そ のガラス転移に起因する高温側の緩和が小さくなること が考えられる. Fig. 3 に示した結果は確かにそのとおり であるため, 上述の推定は妥当なものであることがわか った。

\section{4 結 論}

塩素化ポリエチレンとヒンダードアミン系低分子化合 物からなる有機ハイブリッドについて，熱処理による相 分離, 結晶化の過程における動的粘弾性の変化などを調 べ，次のような結果を得た。

1） $160^{\circ} \mathrm{C}$ でプレスした CPE/LA-57（50/50）試料はほ ほ単一の緩和を示すため, 相溶系である。しかし, CPE と LA-57 の間では異分子間の水素結合を形成しなかっ た.

2）相溶試料を $100^{\circ} \mathrm{C}$ で熱処理すると，まず動的粘弾
性に二つの緩和が現れ，その後高温側の緩和が段々小さ くなり，最後に消失することが見られた。これに対応し て熱処理過程における構造変化としてまず相分離による アモルファスのLA-57ドメインが形成され, 続いて結 晶化が急速に進行していくことを明らかにした，熱処理 の後期過程で見られた $E^{\prime}$ の大幅な増大は, CPEのセグ メントを取り込んでいる LA-57 の結晶がフィラーとし てだけでなく，架橋点としても働いたためであると考え られる.

謝 辞 本研究において試料の提供および作製に協力いただい た昭和電工(株)の荒川努氏，熊木輝利氏に深く感謝致します。

\section{文献}

1) C. Wu, T. Yamagishi, Y. Nakamoto, S. Ishida, K. Nitta, and S. Kubota, J. Polym. Sci, Part B: Polym. Phys., 38, 2285 (2000).

2) C. Wu, S. Akiyama, T. Mabuchi, and K. Nitta, Polym. J., 33, 792 (2001).

3) C. Wu, Chin. J. Polym. Sci., 19, 455 (2001).

4) C. Wu, T. Yamagishi, Y. Nakamoto, S. Ishida, S. Kubota, and K. Nitta, J. Polym. Sci., Part B: Polym. Phys., 38, 1496 (2000).

5) C. Wu, J. Polym. Sci., Part B: Polym. Phys., 38, 2943 (2001).

6) C. Wu, Y. Otani, N. Namiki, H. Emi, and K. Nitta, Polym. J., 33, $322(2001)$.

7) 呉馳飛, 新田晃平, 高分子論文集, 57, 449 (2000).

8) 西 敏夫, 日本コム協会誌, 67, 736 (1994).

9) E. Guth, J. Appl. Phys., 16, 20 (1945).

10) H. Tanaka and T. Nishi, Phys. Rev. A: At., Mol., Opt. phys., 39, 783 (1989).

11) 塩見友雄, 綫維学会誌, 55(3), 87 (1999).

Changes in Dynamic Mechanical Properties and Structure of an Organic Hybrid of Chlorinated Polyethylene and Hindered Amine During Heat-Treatment Process

Taiki Tobusawa, ${ }^{* 1}$ Chifei $\mathrm{Wu}^{*}{ }^{* 1,}{ }^{\dagger}$ and Saburo AKIYama ${ }^{* 1}$

*'Department of Organic and Polymer Materials Chemistry, Faculty of Technology, Tokyo University of Agriculture and Technology (Naka-cho, Koganei, Tokyo 184-8588, Japan)

The dynamic mechanical properties and phase separation behavior of organic hybrid consisting of chlorinated polyethylene (CPE) and tetrakis(2,2,6,6-tetramethyl-4-piperidyl)-1,2,3,4-butane tetracarboxylate (LA-57) during heat-treatment process were investigated. The untreated CPE/LA-57 (50/50) sample shows only one relaxation, whereas the samples heat-treated at $100^{\circ} \mathrm{C}$ for a short time show two relaxations. With further increases in heat-treatment time, the relaxation at higher temperature, which is attributed to the glass transition of LA-57 domain resulting from phase separation, was found to be reduced. In addition, when heat-treatment time was extended to 180 min, this relaxation disappeared. This change in dynamic mechanical properties can be attributed to the recrystallization of LA-57 molecules during heat-treatment process. The evidence of the recrystallization of LA-57 was obtained from DSC measurements.

KEY WORDS Chlorinated Polyethylene / Hindered Amine / Dynamic Mechanical Property / Phase Separation / Organic Hybrid / Crystallization / Heat-Treatment /

(Received March 1, 2002: Accepted April 12, 2002)

[Kobunshi Ronbunshu, 59(7), 427-431(2002)]

\footnotetext{
${ }^{\dagger}$ Present address: Institute of Material Science and Technology, East China University of Science and Technology, (130 Mellong-lu, Shanghai 200237, China)
} 